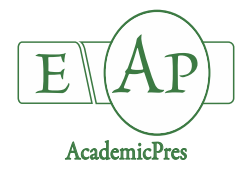

Toader M et al. (2020)
Notulae Botanicae Horti Agrobotanici Cluj-Napoca 48(3):1413-1425
DOI: $10.15835 /$ nbha48311973
Research Article

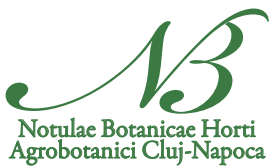

\title{
Research on the morphology, biology, productivity and yields quality of the Amaranthus cruentus L. in the southern part of Romania
}

\author{
Maria TOADER ${ }^{1}$, Alina M. IONESCU ${ }^{1}$, Cosmin ȘONEA $^{1 *}$, \\ Emil GEORGESCU²
}

\author{
${ }^{1}$ University of Agronomic Sciences and Veterinary Medicine of Bucharest, Faculty of Agriculture, 59 Marasti Blvd, District 1, \\ 011461,Bucharest,Romania; maria.toader@agro-bucuresti.ro; alinamariaionescu@yahoo.com; \\ cosmin_sn@yahoo.com ("corresponding author) \\ ${ }^{2}$ National Agricultural Research and Development Institute of Fundulea, Plant Protection Department, 1 N. Titulescu Street, \\ Calarasi, Romania; emilgeorgescu2013@gmail.com
}

\begin{abstract}
Currently, according to the specialists in the field, Amaranthus species are part of alternative agricultural crops recommended for organic farming. In this context, our scientific approach is to analyse the adaptability of these species in the specific conditions of the southern part of Romania (Reviga village, Ialomita County). Thus, for two consecutive years, two varieties of Amaranthus cruentus, namely 'Bolivia 153' and 'Golden Giant', were studied regarding: morphology, biology, cultivation technology, plant productivity and quality of yields in the organic farming conditions. After the study period, the 'Golden Giant' variety was characterized by the following: 8 days - sowing-emergence period; flowering start on 21 July; 124 days - vegetation period; 839.3 Growing Degree Days (GDD) $\left(\Sigma \mathrm{t}^{\circ} \mathrm{C}>15^{\circ} \mathrm{C}\right) ; 23.24 \mathrm{~g}$ - grains mass per plant; $1.375 \mathrm{~g}$ - Thousand Weight Grains (TWG); 2,647 $\mathrm{kg} \mathrm{ha}^{-1}$ - grains yields. By comparison, 'Bolivia 153' variety plants were presented as follows: 11 days - sowing-emergence period; flowering start on 21 July; 127 days - vegetation period; 842.4 GDD; $22.09 \mathrm{~g}$ - grains mass per plant; $1.46 \mathrm{~g}$ TWG; $23.78 \mathrm{~kg} \mathrm{ha}^{-1}$ - grains yields. In average, the chemical composition of Amaranthus cruentus grains was: $15.20 \%$ proteins; $51.70 \%$ starch; $5.96 \%$ lipids; $13.36 \%$ cellulose and $3.35 \%$ ash. In conclusion, the experimentation area proved to be favourable to Amaranthus cruentus cultivation, so that the tested varieties behaved well, had a fairly uniform emergences, and the good level of grains yields and quality.
\end{abstract}

Keywords: alternative crops; Amaranthus cruentus; grains yield; organic agriculture; yields quality

\section{Introduction}

The economic, social and political evolution of human society in the last decades has brought to the fore the question of natural resources, scientists increasingly asking the extent to which these resources will be able to support economic development in the future and will provide food for a growing population, and will contribute to the eradication of underdevelopment (FAO, 2017). The accentuation of major socio-economic phenomena (demographic explosion, tendency of natural resources depletion, deterioration of the quality of the environment, pollution), have led to search and to find the alternative solutions for a sustainable perspective 
of the environment and biodiversity (Haros and Schoenlechner, 2017). In this context, the organic farming system is also included, as an alternative system of agricultural production, which respects the environment, biodiversity and natural resources. Also, alternative crops promoted by organic farming system are based on these principles and represent an alternative of the plant species commonly cultivated by farmers. An alternative crop could be defined as an agronomic crop not usually grown in a geographic reason, selected for use due to potential high sale value or specialized benefit to the farming system (Isleib, 2012). A crop can be very common in one geographic area and considered an alternative in another (Isleib, 2012). Crop diversity is a key tenet of organic agriculture. Having multiple crops that fill distinct niches in an agroecosystem improves the ability to manage weeds, diseases and insect pests as well as potentially improving the environmental performance of the cropping system (Duwayri, 2001). Research can help overcome production and market obstacles that enable the successful introduction of alternative crops (FAO, 2017). Risk reduction through diversification (related to climatic and biotic vagaries, particularly in fragile ecosystems and commodity fluctuations) by expanding locally adapted or introducing novel varieties and related production systems, will contribute to improved food security and income generation for resource poor farmers and protect the environment (Duwayri, 2001). In this sense, Amaranthus species with Chenopodium quinoa, represented the most popular alternative crop species. These species have the centres of origin in South America and were brought in Europe by the Spanish conquistadors, as an ornamental plant (16th century). Until the sec. XIX the Amaranthus species were used as an ornamental plant, but also for the consumption of green leaves, in most areas with tropical climate, and in Africa it became an important vegetable (Cole, 1979). Amaranth is a crop with high potential for economic exploitation similar to maize, wheat, sorghum, barley, rice, and soybean (Innovation NRCACT, 1984; Rastogi and Shukla, 2013; Akin-Idowu, 2017). Amaranth has an excellent nutritional value and high genetic and phenotypic diversity. Their valuable nutritional content, their adaptability to harsh environments, their diversity of uses, and the food culture and traditions associated with these grains, are at the basis of their extensive use in the Andes over centuries (Giuliani et al., 2012). Amaranthus species have different uses: mixtures of cereals for bread or for breakfast, crêpes, pastries, cakes, as raw material in the industry (syrups, diet products, starch, and oil), salads. They can be used as an excellent feed for animals, but also as medicinal plants, in digestive disorders or as a disinfectant (Toader and Roman, 2011).

Amaranthus species is considered to potentially offer an alternative crop in temperate and tropical climate (Das, 2016). In recent decades, amaranth grain has been extensively studied for its remarkable nutritional profile and agricultural characteristics, e.g., having a short cultivation period and being drought resistance (Najdi Hejazi et al., 2016). Introduction of amaranth as a human food has been slow, but today it is produced and used as a grain or leafy vegetable in India, China, Southeast Asia, Mexico, the Andean highlands in South America and the United States (Robert, 1996). The Nebraska panhandle has become the most concentrated area of production of grain amaranth in the US (Rani, 2017). This statement is supported because the crop is easy to cultivate and is not pretentious with the cultivation conditions, it can also be used as a flour for obtaining pasta, but also for extracting lysine and tryptophan, starch, oil squalane, substances needed for the drug or cosmetics industry (Alvarez-Jubete et al., 2010). The leaves can be consumed as a soup, but also for the extraction of proteins, dyes or inflorescences can be used for various decorations (Toader and Roman, 2011). Amaranthus grains have a high nutritional value due to the presence, in a large quantity, of important biochemical compounds for human nutrition and health (Nadathur, 2016). Most of the biochemical components (proteins, lipids, minerals, vitamins), are present in greater quantity, compared to other species (Nadathur, 2016). Orona-Tomayo and Paredes-Lopez, in 2017, reported that, for the different Amaranthus species, proteins can reach up to $19.3 \%$, even $20 \%$; the richness of the essential amino acids was also highlighted: $5-7 \%$ lysine ( $100^{-1}$ g protein), 3-4\% tryptophan, 3-4\% leucine, which gives it a high nutritional value compared to the conventional cereals (Orona-Tamayo and Paredes-Lopez, 2017).

Information about the phenological growth stages of crops is fundamental and useful to agriculture. These researches can provide valuable data for the planning, organization and timely execution of certain agricultural activities such as those of prevention and protection that require detailed information on 
the specific vegetation phases of a crop (the appearance of the inflorescences, the flowering, the stages of maturity, etc.). These data can be used in mathematical modelling, which can predict the timing of phenological events according to certain conditions: temperature, precipitation, duration of sun shine, etc (Tonnang et al., 2018, Erten et al., 2014).

However, details about the growth and development of amaranth is fundamental to its cultivation, but reports on the phenological growth stages, development, and the life cycle of amaranth are limited (MartínezNúñeza et al., 2019; Artemyeva et al., 2019). The importance of this research derives from the improve knowledge about ecology, biology and productivity of Amaranthus cruentus in South part of Romania, also about possibility to introduce of this plant in crops rotation system of organic farming.

\section{Materials and Methods}

\section{Experimental design}

The research was organized with the purpose of studying the morphology, biology, productivity and yields quality of Amaranthus cruentus species, respectively, two varieties, 'Bolivia 153' and 'Golden Giant', in terms of adaptability to the organic farming conditions of Romanian, in 2017-2018 period.

The experimental field belongs to a farm in Reviga village ( $\left.44^{\circ} 41^{\prime} 34^{\prime \prime} \mathrm{N} 27^{\circ} 06^{\prime} 26^{\prime \prime} \mathrm{E}\right)$ (Ialomita County), in South part of Romania. The sites were managed according to organic agriculture guidelines (EC 834/2007 and EC 889/2008). The farm soil was analysed by Ialomita County Office of Pedological and Agrochemistry Studies. The $\mathrm{pH}$ of soil was weakly acidic oscillating between 6.1-6.5, in average 6.3. Total soluble salts for the analysed samples indicate soil without salinization problems (non-saline soils, with values $<0.100 \%$ ). Mineral nitrogen represents the amount of soil content in changeable and accessible form nitric and ammoniacal

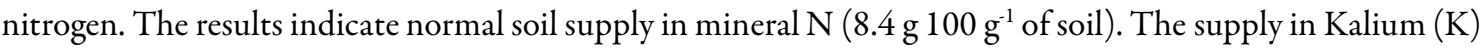
(potentially assimilable) extractable in Aluminium of the soil is very good for the analysed samples $(>200 \mathrm{~K}$ ppm). Content in humus was medium supplied for the analysed soil (2.1-4.0\% humus).

The biological material for sowing came from Germany, certified by the inspection and certification body for organic agriculture system. The previous crops were peas (Pisum sativum, pulses crops category) to benefit from the nitrogen fixed by this plant. No other fertilizer was applied.

The soil tillage consisted in a disking after the harvesting of the previous crop and the release of vegetal debris, followed by the plowing at $25-30 \mathrm{~cm}$ depth. In the spring, the field was disked, followed by the preparation of the germinal bed with the combiner, at a depth of 6-8 $\mathrm{cm}$.

The sowing was done by hand, in 20 of April for both years, at a depth of $1-2 \mathrm{~cm}$. The area of the plot was $5 \mathrm{~m}-2$ (2.5 m long, $2 \mathrm{~m}$ wide). The experiment was organised by Randomized Block Design Method, in four replications. The density was 100,000 grains $\mathrm{ha}^{-1}$, with $50 \mathrm{~cm}$ between plants rows. During on the vegetation period the weed control was executed manually. Other pest or diseases not observed. The harvesting was made manually.

\section{Collecting data, measurements and methods}

During the vegetation period until harvesting, phenological observations and biometric measurements of Amaranthus plants were made on the dynamics (at each 8-10 days). Determinations concerned: emergence date, plants height, nodes of stem, leaves formation and their number, Leaf Area Index, appearance data of inflorescence, flowering, maturity and crop density.

Growing Degree Days (GDD) has been used to calculate the durations and thermal requirements for each phenophase. "To calculate the daily thermal units, the equation of Gilmore and Rogers (1958) was used $\left(\mathrm{GGD}=\left[(\mathrm{Tmax}+\mathrm{Tmin}) 2^{-1}\right]-\mathrm{Tb}\right)$, where $T \max -T \min$ are daily maximum and minimum air temperatures, respectively, $\mathrm{Tb}$ is the base temperature, evaluated at $15^{\circ} \mathrm{C}$ (Gilmore and Rogers, 1958)". The maximum and minimum daily temperatures were obtained from Ialomita weather station. The average multiannual 
temperature was $10.5^{\circ} \mathrm{C}$, with $1.0^{\circ} \mathrm{C}$ higher than Romania's average multiannual temperature of $9.5^{\circ} \mathrm{C}$. The hottest month of the years was July, with a monthly average of $22.1^{\circ} \mathrm{C}$, followed by August with $21.1^{\circ} \mathrm{C}$, and the coldest was January with $-3.0^{\circ} \mathrm{C}$. Separately by years it is found that in the years of experimentation, the temperatures have registered great differences in comparison with the multiannual monthly averages. Thus, for the year 2017-2018, the values of the average monthly temperature were recorded with $2.0-6.5^{\circ} \mathrm{C}$ higher than the multiannual average. The warmest month was June, with the average temperature higher by $6.5^{\circ} \mathrm{C}$ than the multiannual average; at a slight difference were the temperatures in July, with $5.7^{\circ} \mathrm{C}$ and August, with 4.5 ${ }^{\circ} \mathrm{C}$ (Figure 1).

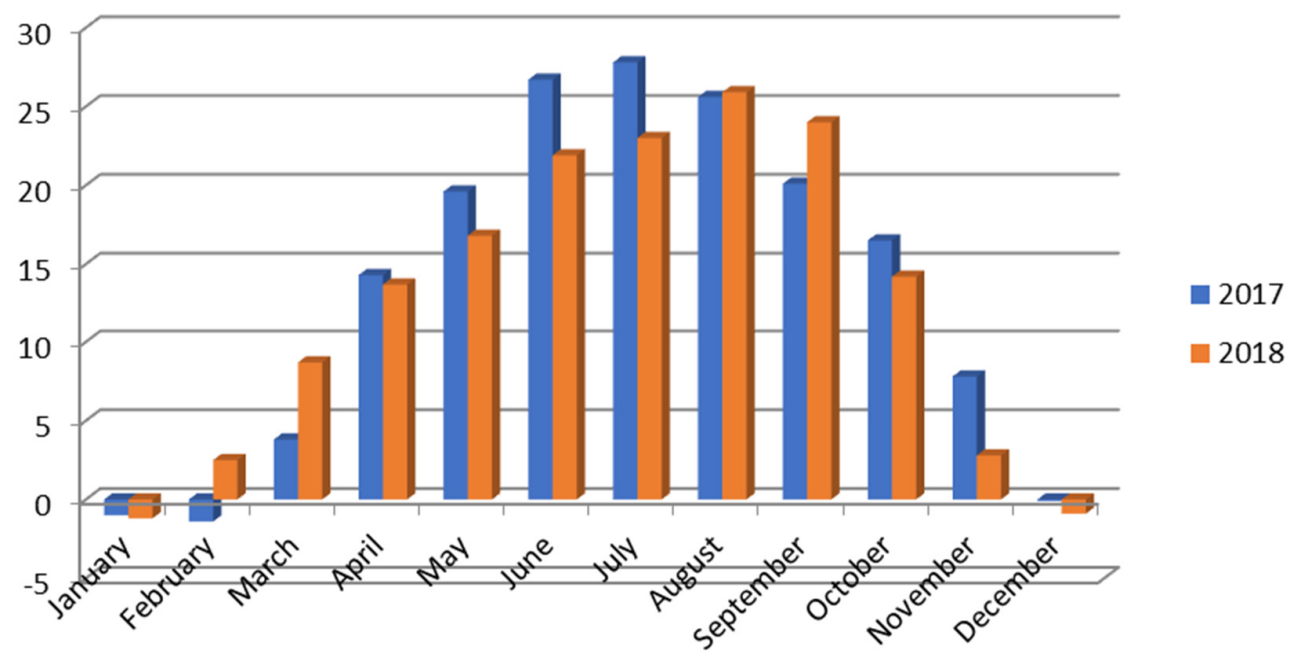

Figure 1. Average air temperature registered in experimental area

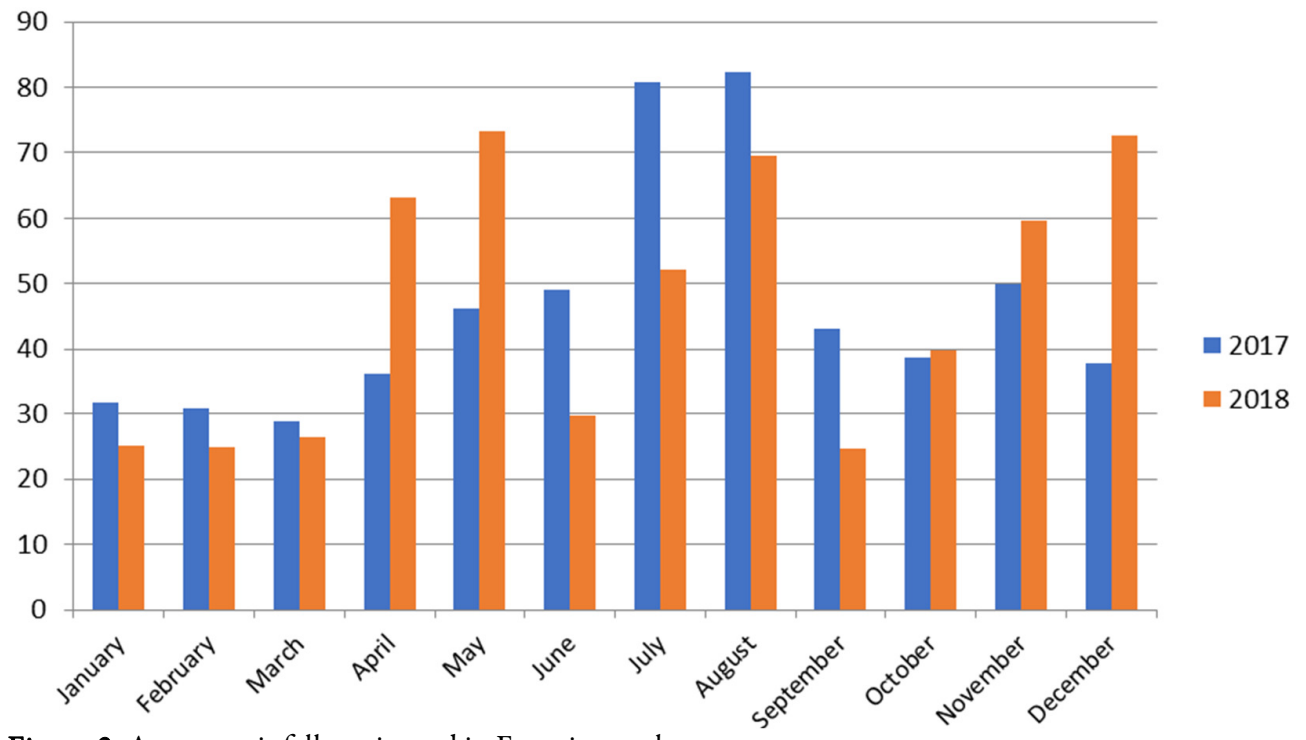

Figure 2. Average rainfalls registered in Experimental area

For the second year of the research (2018) the annual amount of rainfall was $561.3 \mathrm{~mm}$, slightly higher than the multiannual average of $556.1 \mathrm{~mm}$. In this agricultural year the richest precipitations were recorded in May $(73.4 \mathrm{~mm})$, more with $5.7 \mathrm{~mm}$, followed by December $(72.6 \mathrm{~mm})$, with $35.9 \mathrm{~mm}$ more than the average, 
multiannual monthly. The amount of precipitation in October, November and December was $172 \mathrm{~mm}$, compared to $113.1 \mathrm{~mm}$, which was the multiannual average. The smallest quantities were registered in February $(24.8 \mathrm{~mm})$ with a deficit of $7.3 \mathrm{~mm}$ compared to the multiannual average and September $(24.7 \mathrm{~mm})$, with a minus of $8.9 \mathrm{~mm}$ (Figure 2).

10 plants from each plot were used for determinations of productivity elements in laboratory. Have been eliminated the marginal plants to avoid the possible errors. After manually harvesting, in laboratory was made the number and quantity of grains per plants and TWG. For the TWG determination was used the standard method with 2 repetitions of 500 pure seeds.

Chemical analyses of grains were performed in Yields Quality Laboratory of Crop Science Department, Faculty of Agriculture, University of Agronomic Sciences and Veterinary Medicine of Bucharest. The equipment was a spectrophotometer (Instalab 600) calibrated by a company from Novisad (Serbia) to determine the content of dry matter, crude protein, starch, lipids, cellulose and ash. The Instalab 600 uses Near Infrared (NIR) technology and a statistical math treatment to predict the percent of constituent concentration within a sample.

\section{Statistical procedures}

Data presentation was done by processing the media for replications and for years. Significant statistical differences were determined by the Fisher's least significant differences (LSD) test and also the Student Neuman Keuls (SNK) test with the ARM 8.5 program.

\section{Results and Discussion}

\section{Dynamics of plants height}

From the analysis of the data contained in Table 1, it turns out that, in 2017-2018 periods, no significant differences were found between the varieties experienced, in terms of vegetation dynamics.

Under normal conditions, amaranth plants are as high as $2.2 \mathrm{~m}$, making their handling difficult (Martínez-Núñeza et al., 2019). On average, the emergence was observed after 12 days of sowing, for the 'Bolivia 153 ' variety and after 15 days for the 'Golden Giant' variety. The duration of the vegetation period was 124 days for the 'Golden Giant' variety and 3 days longer for the 'Bolivia 153' variety, and the thermal consumption had values close to both varieties, namely 839.3 GDD for the 'Golden Giant' variety and 842.4 GDD for the 'Bolivia 153' variety.

The inflorescence appeared after 56 days of vegetation or after accumulation of 248.3 GDD in the case of the 'Bolivia 153' variety, and 2 days later, after the accumulation of 291.2 GDD, in the case of the 'Golden Giant' variety.

In terms of the dynamics of plant growth in height, some differences between varieties were found. Further, until maturity, the growth was $22.9 \mathrm{~cm}$, with an average rate of $0.54 \mathrm{~cm}^{-1}{ }^{-1}$ in the case of the 'Bolivia 153 ' variety, and $18 \mathrm{~cm}$, with an average rate of $0.43 \mathrm{~cm}^{-1} \mathrm{yy}^{-1}$, in the case of the 'Golden Giant' variety.

\section{Dynamics of nodes formation}

The formation of nodes at 'Bolivia 153' variety took place during 71 days of vegetation, in which 12 nodes of stem were formed, with an average rhythm of 5.91 days node ${ }^{-1}$. The first node was observed after 11 days from emergence, when 7.9 GDD were accumulated, and the intervals between the formation of nodes 2 and 5 were on average 7 days node ${ }^{-1}$, with an average consumption of 28.37 GDD node ${ }^{-1}$. In parallel with the intense increase in height of the stem, the rate of node formation also became more alert, so that the following 5 nodes at intervals of 3.6 days node ${ }^{-1}$, with an average thermal consumption of 27.46 GDD node . Node $^{-1}$ formation continued for another 14 days, resulting 2 nodes, at an interval of 7 days node ${ }^{-1}$ and with an average

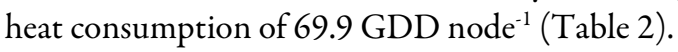


Toader M et al. (2020). Not Bot Horti Agrobo 48(3):1413-1425

Table 1. Dynamics of Amaranthus cruentus plants height (Reviga experimental field)

\begin{tabular}{|c|c|c|c|c|c|c|}
\hline \multirow{2}{*}{ Data } & \multicolumn{3}{|c|}{ 'Bolivia 153' variety } & \multicolumn{3}{c|}{ 'Golden Giant' variety } \\
\cline { 2 - 7 } & $\begin{array}{c}\text { Height } \\
\text { plants }(\mathrm{cm})\end{array}$ & $\begin{array}{c}\text { Days from } \\
\text { emergence }\end{array}$ & $\begin{array}{c}\text { GDD } \\
\left(\Sigma \mathrm{t}>15^{\circ} \mathrm{C}\right)\end{array}$ & $\begin{array}{c}\text { Height } \\
\text { plants } \\
(\mathrm{cm})\end{array}$ & $\begin{array}{c}\text { Days from } \\
\text { emergence }\end{array}$ & $\begin{array}{c}\text { GDD } \\
\left(\Sigma \mathrm{t}>15^{\circ} \mathrm{C}\right)\end{array}$ \\
\hline 12 May & 4.8 & 11 & 5.6 & 3.2 & 8 & 2.7 \\
\hline 21 May & 8.1 & 20 & 32.8 & 6.9 & 17 & 29.7 \\
\hline 28 May & 15.5 & 28 & 63.8 & 13.6 & 25 & 70.7 \\
\hline 3 June & 29.5 & 35 & 104.2 & 26.9 & 33 & 101.1 \\
\hline 10 June & 51.7 & 42 & 136.7 & 37.9 & 39 & 133.6 \\
\hline 18 June & 63.4 & 50 & 189.2 & 54.7 & 47 & 186.1 \\
\hline 24 June & 81.8 & 56 & 248.3 & 76.5 & 53 & 245.2 \\
\hline 1 July & 106.6 & 63 & 323.2 & 100.3 & 60 & 320.1 \\
\hline 9 July & 118.9 & 71 & 399 & 116.6 & 68 & 395.9 \\
\hline 16 July & 137.8 & 78 & 455.7 & 125.9 & 75 & 452.6 \\
\hline 23 July & 143.8 & 85 & 518.2 & 131.8 & 83 & 515.1 \\
\hline 30 July & 149.8 & 92 & 568.3 & 135.3 & 89 & 565.2 \\
\hline 7 August & 152.2 & 100 & 643.8 & 138.6 & 97 & 640.7 \\
\hline 14 August & 157.5 & 107 & 707.5 & 141.9 & 104 & 704.4 \\
\hline 21 August & 161.5 & 114 & 769.3 & 143.8 & 111 & 766.2 \\
\hline 28 August & 165.5 & 121 & 815.2 & 147.5 & 118 & 812.1 \\
\hline 3 September & 166.7 & 127 & 842.4 & 149.8 & 124 & 839.3 \\
\hline
\end{tabular}

Table 2. Dynamics of stem nodes (Reviga experimental field)

\begin{tabular}{|c|c|c|c|c|c|c|c|}
\hline \multicolumn{8}{|c|}{ Nodes per plant } \\
\hline \multicolumn{4}{|c|}{ 'Bolivia 153 ' variety } & \multicolumn{4}{|c|}{ 'Golden Giant' variety } \\
\hline \multirow[b]{2}{*}{$\begin{array}{c}\text { Number of } \\
\text { stem nodes } \\
\text { (Average) }\end{array}$} & \multicolumn{2}{|c|}{ Period } & \multirow[b]{2}{*}{$\begin{array}{c}\text { GDD } \\
\left(\Sigma \mathrm{t}>15^{\circ} \mathrm{C}\right)\end{array}$} & \multirow[b]{2}{*}{$\begin{array}{c}\text { Number of } \\
\text { stem nodes } \\
\text { (Average) }\end{array}$} & \multicolumn{2}{|c|}{ Period } & \multirow[b]{2}{*}{$\begin{array}{c}\text { GDD } \\
\left(\Sigma \mathrm{t}>15^{\circ} \mathrm{C}\right)\end{array}$} \\
\hline & $\begin{array}{l}\text { Days from } \\
\text { emergence }\end{array}$ & $\begin{array}{c}\text { Days of } \\
\text { previous } \\
\text { node } \\
\text { formation }\end{array}$ & & & $\begin{array}{l}\text { Days from } \\
\text { emergence }\end{array}$ & $\begin{array}{c}\text { Days of } \\
\text { previous } \\
\text { node } \\
\text { formation }\end{array}$ & \\
\hline 1 & 11 & - & 7.9 & 1 & 13 & - & 14.1 \\
\hline 2 & 20 & 9 & 34.9 & 2 & 21 & 8 & 51.3 \\
\hline 3 & 27 & 7 & 62.8 & 3 & 27 & 6 & 78.9 \\
\hline 4 & 33 & 6 & 96.4 & 4 & 33 & 6 & 101.1 \\
\hline 5 & 39 & 6 & 121.9 & 5 & 38 & 5 & 128.6 \\
\hline 6 & 43 & 4 & 144.1 & 6 & 42 & 4 & 161.4 \\
\hline 7 & 47 & 4 & 169.4 & 7 & 45 & 3 & 175 \\
\hline 8 & 50 & 3 & 189.2 & 8 & 47 & 2 & 186.1 \\
\hline 9 & 53 & 3 & 212.5 & 9 & 50 & 3 & 211.8 \\
\hline 10 & 57 & 4 & 259.2 & 10 & 55 & 5 & 281.7 \\
\hline 11 & 63 & 6 & 323.2 & 11 & 60 & 5 & 321.1 \\
\hline 12 & 71 & 7 & 399 & 12 & 67 & 7 & 388.6 \\
\hline- & - & - & - & 13 & 75 & 8 & 452.6 \\
\hline
\end{tabular}




\section{Dynamics of leaves formation}

The dynamics of leaves formation is presented in Table 3.

The plants of the 'Golden Giant' variety formed during 75 days of vegetation and after a thermal consumption of $452.6 \mathrm{GDD}, 13$ nodes, with an average rhythm of 5.76 days node $^{-1}$.

The formation of the first node, for 'Golden Giant' variety, was noted 13 days after emergence, after a thermal consumption of $14.1 \mathrm{GDD}$, and the following 4 nodes were formed within a period of 25 days, with an average rhythm of 6.25 days node ${ }^{-1}$ and an average consumption of 28.62 GDD node $e^{-1}$. The formation of nodes 6-9 was staggered over 12 days, the average rhythm being 3 days node ${ }^{-1}$ and the thermal consumption of 12.6 GDD node ${ }^{-1}$. The process of node formation continued for another 20 days, resulting 4 nodes, with an average rhythm of 5 days node ${ }^{-1}$.

Table 3. Dynamics of Amaranthus cruentus leaves formation (Reviga experimental field)

\begin{tabular}{|c|c|c|c|c|c|c|c|c|}
\hline \multirow[b]{3}{*}{ Data } & \multicolumn{4}{|c|}{ 'Bolivia 153 ' variety } & \multicolumn{4}{|c|}{ 'Golden Giant' variety } \\
\hline & \multicolumn{2}{|c|}{ Number of leaves } & \multirow[b]{2}{*}{$\begin{array}{c}\text { Days } \\
\text { (from } \\
\text { emergence) }\end{array}$} & \multirow[b]{2}{*}{$\begin{array}{c}\text { GDD } \\
\left(\sum \mathrm{t}>15\right. \\
\left.{ }^{\circ} \mathrm{C}\right)\end{array}$} & \multicolumn{2}{|c|}{ Number of leaves } & \multirow[b]{2}{*}{$\begin{array}{c}\text { Days } \\
\text { (from } \\
\text { emergence) }\end{array}$} & \multirow[b]{2}{*}{$\begin{array}{c}\text { GDD } \\
\left(\sum \mathrm{t}>15\right. \\
\left.{ }^{\circ} \mathrm{C}\right)\end{array}$} \\
\hline & $\begin{array}{c}\text { From } \\
\text { sowing }\end{array}$ & $\begin{array}{l}\text { Days of the } \\
\text { previous leaf's } \\
\text { formation }\end{array}$ & & & $\begin{array}{c}\text { From } \\
\text { sowing }\end{array}$ & $\begin{array}{c}\text { Days of the } \\
\text { previous leafs } \\
\text { formation }\end{array}$ & & \\
\hline 12 May & 2 & 0 & 11 & 5.6 & 2 & - & 8 & 2.7 \\
\hline 21 May & 4 & 2 & 20 & 32.8 & 3 & 1 & 17 & 29.7 \\
\hline 28 May & 6 & 2 & 28 & 63.8 & 5 & 2 & 25 & 70.7 \\
\hline 3 June & 8 & 2 & 35 & 104.2 & 7 & 3 & 33 & 101.1 \\
\hline 10 June & 11 & 3 & 42 & 136.7 & 10 & 3 & 39 & 133.6 \\
\hline 18 June & 15 & 4 & 50 & 189.2 & 14 & 4 & 47 & 186.1 \\
\hline 24 June & 21 & 6 & 56 & 248.3 & 20 & 6 & 53 & 245.2 \\
\hline 1 July & 26 & 5 & 63 & 323.2 & 26 & 6 & 60 & 320.1 \\
\hline 9 July & 30 & 4 & 71 & 399 & 30 & 4 & 68 & 395.9 \\
\hline 16 July & 33 & 3 & 78 & 455.7 & 33 & 3 & 75 & 452.6 \\
\hline 23 July & 35 & 2 & 85 & 518.2 & 35 & 2 & 83 & 515.1 \\
\hline 30 July & 36 & 1 & 92 & 568.3 & 37 & 2 & 89 & 565.2 \\
\hline 7 August & 29 & - & 100 & 643.8 & 38 & 1 & 97 & 640.7 \\
\hline 14 August & 23 & - & 107 & 707.5 & 28 & - & 104 & 704.4 \\
\hline 21 August & 18 & - & 114 & 769.3 & 24 & - & 111 & 766.2 \\
\hline 28 August & 13 & - & 121 & 815.2 & 18 & - & 118 & 812.1 \\
\hline 3 September & 8 & - & 127 & 842.4 & 11 & - & 124 & 839.3 \\
\hline
\end{tabular}

In the case of the 'Bolivia 153' variety, the leaves formation (36 leaves in total) was carried out over a period of 92 days of vegetation, in which the thermal accumulation was $568.3 \mathrm{GDD}$; the average rate was 2.55 days leaf ${ }^{-1}$ and the average heat consumption was $15.68 \mathrm{GDD} \mathrm{leaf}^{-1}$. On May 12, after 11 days from emergence, Amaranthus plants belong to the 'Bolivia 153' variety had 2 leaves, with a leaves area of $1.1 \mathrm{~cm}-2$ plant ${ }^{-1}$; after 29 days, the number of leaves reached 11 leaves, with an area of $529.3 \mathrm{~cm}-2$ plant $^{-1}$, resulting in an average rate of 2.63 days leaf $^{-1}$ and an average consumption of 12.42 GDD leaf $^{-1}$. There were 29 days when the rate of leaf development was more alert. In this interval, 19 leaves were formed, with an average rate of 1.52 days leaf $^{-1}$ and a thermal consumption of 13.8 GDD leaf ${ }^{-1}$; at the end of this interval, the Leaf Area Index was $2543.7 \mathrm{~cm}-2$ plant $^{-1}$. The maximum value of the leaves surface, of $3,401.6 \mathrm{~cm}-2$ plant $^{-1}$, was reached 21 days later, when the plants had a total of 36 leaves (Table 3).

Table 4 contain data regarding Leaf Area Index of Amaranthus cruentusvarieties, in 2017-2018 periods. 
Toader M et al. (2020). Not Bot Horti Agrobo 48(3):1413-1425

Table 4. Dynamics of Amaranthus cruentus Leaf Area Index (Reviga experimental field)

\begin{tabular}{|c|c|c|c|c|c|c|}
\hline \multirow[b]{3}{*}{ Data } & \multicolumn{3}{|c|}{ 'Bolivia 153 ' variety } & \multicolumn{3}{|c|}{ 'Golden Giant' variety } \\
\hline & \multicolumn{2}{|c|}{ Leaf Area Index $\left(\mathrm{cm}-2\right.$ plant $\left.^{-1}\right)$} & \multirow[b]{2}{*}{$\begin{array}{l}\text { Days from } \\
\text { emergence }\end{array}$} & \multicolumn{2}{|c|}{ Leaf Area index $\left(\mathrm{cm}-2\right.$ plant $\left.^{-1}\right)$} & \multirow[b]{2}{*}{$\begin{array}{l}\text { Days from } \\
\text { emergence }\end{array}$} \\
\hline & Value & $\begin{array}{l}\text { Days of previous } \\
\text { nodes formation }\end{array}$ & & Value & $\begin{array}{c}\text { Days of } \\
\text { previous nodes } \\
\text { formation }\end{array}$ & \\
\hline 12 May & 1.1 & - & 11 & 0.9 & - & 8 \\
\hline 21 May & 28.6 & 27.5 & 20 & 21.4 & 20.4 & 17 \\
\hline 28 May & 57.9 & 29.3 & 28 & 46.2 & 24.7 & 25 \\
\hline 3 June & 123.1 & 65.2 & 35 & 115.9 & 69.7 & 33 \\
\hline 10 June & 529.3 & 406.2 & 42 & 489.5 & 373.6 & 39 \\
\hline 18 June & $1,208.7$ & 679.4 & 50 & $1,023.7$ & 534.2 & 47 \\
\hline 24 June & $1,723.9$ & 515.2 & 56 & $1,598.4$ & 574.7 & 53 \\
\hline 1 July & $2,183.6$ & 359.7 & 63 & $2,034.6$ & 436.2 & 60 \\
\hline 9 July & $2,543.7$ & 260.1 & 71 & $2,353.9$ & 319.3 & 68 \\
\hline 16 July & $2,897.5$ & 254 & 78 & $2,772.8$ & 418.9 & 65 \\
\hline 23 July & $3,264.9$ & 67.4 & 85 & $3,148.9$ & 376.1 & 83 \\
\hline 30 July & $3,401.6$ & 36.7 & 92 & $3,318.9$ & 170 & 89 \\
\hline 7 August & $3,001.5$ & - & 100 & $3,357.7$ & 38.8 & 97 \\
\hline 14 August & $2,009.5$ & - & 107 & $3,189.3$ & - & 104 \\
\hline 21 August & $1,201.9$ & - & 114 & $1,959.3$ & - & 111 \\
\hline 28 August & 678.5 & - & 121 & 984.5 & - & 118 \\
\hline 3 September & 245.6 & - & 127 & 395.7 & - & 124 \\
\hline
\end{tabular}

Regarding the dynamics of leaves formation for the 'Golden Giant' variety, it can be emphasized that the more alert rate was noticed during the period June 10-July 16, in which 23 leaves were formed. In this interval the sum of the useful temperatures was 319 GDD, resulting an average of 1.60 days leaf $^{-1}$ formation rate and a consumption of 13.86 GDD leaf ${ }^{1}$. On May 12 (after 8 days after emergence) the Leaf Area Index was $0.9 \mathrm{~cm}-2$ plant $^{-1}$, then, as the vegetation advanced, the leaf area evolved upwards, so that on June 3 or after the accumulation of 101.1 GDD the leaf surface reached $115.9 \mathrm{~cm}-2$ plant ${ }^{-1}$; a month later, on July 1 , a leaf area of 2,034.6 cm-2 plant $^{-1}$ was determined, and a maximum leaf area of $3,357.7 \mathrm{~cm}-2$ plant ${ }^{-1}$ was reached on August 7 , after accumulating 640.7 GDD.

\section{Dynamics of inflorescence formation, flowering and grains formation}

Under the conditions of 2017 year, the inflorescence appeared on the 'Bolivia 153' variety plants after 56 days after emergence or 248.3 GDD accumulations, while on the 'Golden Giant' variety plants, the beginning of the inflorescence formation was noted after 58 days after the emergence, and a thermal accumulation of 291.2 GDD. The beginning of flower opening was started after 22 of days for 'Bolivia 153' variety and 23 days for 'Golden Giant' variety. The maturity stages developed during 35 of days for "Bolivia 153 ' variety and 9 days faster for the 'Golden Giant' maturity. The full maturity means 842.4 GDD of 'Bolivia 153 ' variety and 839.3 GDD of 'Golden Giant' variety (Table 5).

\section{Productivity elements and grains yields}

Following the analysis of the productivity elements, the 'Bolivia 153 ' variety has a number of 13,660 grains per plant, with a mass of 18.23 g plant $^{-1} ; 15,876$ grains plant $^{-1}$ were determined at the 'Golden Giant' variety, their grains mass being $21.75 \mathrm{~g}$ plant $^{-1}$, in 2017. In 2018, the values were superior at all indexes. TWG was $1.41 \mathrm{~g}$ of the 'Bolivia 153' variety, being characterized by slightly larger grains, with TWG of $1.45 \mathrm{~g}$, while the 'Golden Giant' variety formed smaller grains, with a TWG of $1.37 \mathrm{~g}$ (Table 6). 
Table 5. Dynamics of Amaranthus cruentus inflorescence formation, flowering and grains formation (Reviga experimental field)

\begin{tabular}{|c|c|c|c|c|c|}
\hline $\begin{array}{c}\text { Amaranthus } \\
\text { cruentus } \\
\text { varieties } \\
\end{array}$ & Data & $\begin{array}{c}\text { Length of } \\
\text { inflorescence } \\
(\mathrm{cm})\end{array}$ & Phenophase & $\begin{array}{l}\text { Days from } \\
\text { emergence }\end{array}$ & $\begin{array}{c}\text { GDD } \\
\left(\sum \mathrm{t}>15^{\circ} \mathrm{C}\right)\end{array}$ \\
\hline \multirow{6}{*}{ 'Bolivia 153' } & 24 June & 1.8 & $\begin{array}{l}\text { The appearance of the } \\
\text { inflorescence }\end{array}$ & 56 & 248.3 \\
\hline & 9 July & 15.6 & - & 71 & 399 \\
\hline & 16 July & 25.4 & $\begin{array}{l}\text { The beginning of the } \\
\text { flower opening }\end{array}$ & 78 & 455.7 \\
\hline & 30 July & 32.6 & $\begin{array}{l}\text { The beginning of } \\
\text { grains formation }\end{array}$ & 92 & 568.3 \\
\hline & 21 August & 35.4 & - & 114 & 769.3 \\
\hline & 3 September & 37.1 & Full maturity & 127 & 842.4 \\
\hline \multirow{6}{*}{ 'Golden Giant' } & 29June & 1.1 & $\begin{array}{c}\text { The appearance of the } \\
\text { inflorescence }\end{array}$ & 58 & 291.2 \\
\hline & 16 July & 13.6 & - & 65 & 452.6 \\
\hline & 21 July & 27.4 & $\begin{array}{l}\text { The beginning of the } \\
\text { flower opening }\end{array}$ & 81 & 493.6 \\
\hline & 5 August & 34.7 & $\begin{array}{l}\text { The beginning of } \\
\text { grains formation }\end{array}$ & 95 & 621.7 \\
\hline & 21 August & 36.9 & - & 111 & 766.2 \\
\hline & 3 September & 39.8 & Full maturity & 124 & 839.3 \\
\hline
\end{tabular}

Table 6. Productivity elements of Amaranthus cruentus (Reviga experimental field)

\begin{tabular}{|c|c|c|c|c|}
\hline Year & Productivity elements & 'Bolivia 153' variety & 'Golden Giant' variety & Average \\
\hline \multirow{5}{*}{2017} & Height of plant $(\mathrm{cm})$ & 166.7 & 149.8 & 158.3 \\
\hline & No of plants ha ${ }^{-1}$, at harvesting & 92,000 & 98,000 & 95,000 \\
\hline & No of grains plant ${ }^{-1}$ & 13,660 & 15,876 & 14,768 \\
\hline & Mass of grains plant ${ }^{-1}(\mathrm{~g})$ & 18.23 & 21.75 & 19.99 \\
\hline & TWG (g) & 1.45 & 1.37 & 1.41 \\
\hline \multirow{5}{*}{2018} & Height of plant $(\mathrm{cm})$ & 178.3 & 169.1 & 173.7 \\
\hline & No of plants ha ${ }^{-1}$, at harvesting & 98,000 & 99,000 & 98,500 \\
\hline & No of grains plant ${ }^{-1}$ & 18,911 & 22,921 & $11,469.96$ \\
\hline & Mass of grains plant ${ }^{-1}(\mathrm{~g})$ & 30.06 & 31.63 & 30.85 \\
\hline & TWG (g) & 1.59 & 1.38 & 1.49 \\
\hline
\end{tabular}

Rusu et al. (2009) and Marin et al. (2011), obtained 2,530.36 kg ha-1 of the grains production of Amaranthus sp. on the Somesan Plateau, out of the 12 Amaranthus varieties studied, 7 recorded grains productions over $4,000 \mathrm{~kg} \mathrm{ha}^{-1}$ (4 varieties belonging to $A$. cruentus L. and 3 varieties of $A$. hypochondriacus L.) (Rusu et al., 2009; Marin et al., 2011).

In our experiments, the grains yields were, in average, 2,002 kg ha-1 in 2017 and 3,023 kg ha' in 2018. Regarding grains yields, the 'Golden Giant' variety surpassed the 'Bolivia 153' variety distinctly significant in both 2017 and 2018 years with $91 \mathrm{~kg} \mathrm{ha}^{-1}$, respectively $179 \mathrm{~kg} \mathrm{ha}^{-1}$ (Table 7). Also, the same variety has a good production in 2018. Also, in 2018, this variety behaved well, significantly exceeding the average. 
Table 7. Grains yields of Amaranthus cruentus varieties (Reviga experimental field)

\begin{tabular}{|c|c|c|c|c|c|c|}
\hline Year & \multicolumn{3}{|c|}{2017} & & \multicolumn{2}{|c|}{2018} \\
\hline Variety & $\begin{array}{c}\text { Grains } \\
\text { yield } \\
\left(\mathrm{kg} \mathrm{ha}^{-1}\right)\end{array}$ & $\begin{array}{c}\text { Difference of } \\
\text { average } \\
\left(\mathrm{kg} \mathrm{ha}^{-1}\right)\end{array}$ & Significance & $\begin{array}{c}\text { Grains yield } \\
\left(\mathrm{kg} \mathrm{ha}^{-1}\right)\end{array}$ & $\begin{array}{c}\text { Difference of } \\
\text { average } \\
\left(\mathrm{kg} \mathrm{ha}^{-1}\right)\end{array}$ & Significance \\
\hline 'Bolivia 153' & 1,822 & -180 & ooo & 2,933 & -90 & oo \\
\hline $\begin{array}{c}\text { 'Golden } \\
\text { Giant' }\end{array}$ & 2,181 & 179 & $* * *$ & 3,114 & 91 & $*$ \\
\hline Average & 2,002 & Control & - & 3,023 & Control & - \\
\hline
\end{tabular}

LSD 5\% $=141 \mathrm{~kg} \mathrm{ha}^{-1} ;$ LSD 5\% $=57.2 \mathrm{~kg} \mathrm{ha}^{-1} ;$ LSD 1\% = $214 \mathrm{~kg} \mathrm{ha}^{-1} ;$ LSD $1 \%=86.6 \mathrm{~kg} \mathrm{ha}^{-1} ;$ LSD $0.1 \%=344 \mathrm{~kg} \mathrm{ha}$

${ }^{1}$; LSD $0.1 \%=139.1 \mathrm{~kg} \mathrm{ha}^{-1}$

\section{Chemical composition and quality yields}

The values for protein content were on average $16.11 \%$. Higher protein content was determined for the 'Golden Giant' variety (17.03\%) and lower in the 'Bolivia 153' variety (15.38\%) (Table 8).

Table 8. Chemical composition of Amaranthus cruentus grains (Reviga experimental field) (\% d.m.)

\begin{tabular}{|c|c|c|c|c|c|}
\hline Variety & Proteins & Starch & Lipids & Cellulose & Ash \\
\hline \multicolumn{6}{|c|}{2017} \\
\hline 'Bolivia 153' & $15.38 \mathrm{c}$ & $51.56 \mathrm{c}$ & $6.41 \mathrm{~d}$ & $5.23 \mathrm{~b}$ & $3.34 \mathrm{~b}$ \\
\hline 'Golden Giant' & $16.82 \mathrm{~b}$ & $52.92 \mathrm{~b}$ & $7.11 \mathrm{a}$ & $6.67 \mathrm{a}$ & $3.41 \mathrm{a}$ \\
\hline Average & 16.10 & 52.24 & 6.76 & 5.95 & 3.375 \\
\hline \multicolumn{6}{|c|}{2018} \\
\hline 'Bolivia 153' & $15.20 \mathrm{~d}$ & $51.45 \mathrm{~d}$ & $6.81 \mathrm{c}$ & $5.05 \mathrm{c}$ & $3.10 \mathrm{~b}$ \\
\hline 'Golden Giant' & $17.03 \mathrm{a}$ & $53.2 \mathrm{a}$ & $6.68 \mathrm{c}$ & $6.67 \mathrm{a}$ & $3.20 \mathrm{c}$ \\
\hline Average & 16.12 & 52.33 & 6.75 & 5.86 & 3.15 \\
\hline 2017-2018 Average & 16.11 & 52.28 & 6.75 & 5.91 & 3.26 \\
\hline \multicolumn{6}{|c|}{ Statistical results } \\
\hline $\operatorname{LSD}(\mathrm{P}=0.05)$ & 0.052 & 0.069 & 0.103 & 0.071 & 0.015 \\
\hline Standard Deviation & 0.032 & 0.043 & 0.064 & 0.044 & 0.010 \\
\hline $\mathrm{CV}$ & 0.2 & 0.08 & 0.95 & 0.75 & 0.29 \\
\hline Bartlett's X2 & 6.556 & 8.972 & 18.194 & 11.345 & 0.971 \\
\hline $\mathrm{P}$ (Bartlett's X2) & 0.087 & $0.03^{*}$ & $0.001^{*}$ & $0.01^{*}$ & 0.808 \\
\hline Replicate F & 1.777 & 1.120 & 0.763 & 1.538 & 1.000 \\
\hline Replicate Prob (F) & 0.2214 & 0.3911 & 0.5425 & 0.2708 & 0.4363 \\
\hline Treatment $\mathrm{F}$ & $3,477.124$ & $1,761.780$ & 81.365 & $1,589.377$ & 936.996 \\
\hline Treatment Prob $(\mathrm{F})$ & 0.0001 & 0.0001 & 0.0001 & 0.0001 & 0.0001 \\
\hline
\end{tabular}

Means followed by same letter do not significantly differ ( $\mathrm{P}=0.05$, Student-Newman-Keuls)

Mean comparisons performed only when AOV Treatment $\mathrm{P}(\mathrm{F})$ is significant at mean comparison OSL.

The starch content was on average $51.7 \%$, with values ranging from $51.0 \%$ in the 'Golden Giant' variety to $52.4 \%$ in the 'Bolivia 153 ' variety. Regarding lipids, 'Bolivia 153 ' is best presented with a content of $6.11 \%$, compared to the 'Golden Giant' variety, at which $5.81 \%$ lipids were determined. The cellulose content was on average $13.36 \%$, a higher value, $15.05 \%$, being registered in the 'Golden Giant' variety, and the ash content was on average $3.3 \%$, the highest value, of $3.4 \%$, being analysed in the 'Bolivia 153 ' variety.

In average, the protein production per ha was $404.9 \mathrm{~kg} \mathrm{ha}^{-1}$. Something more being obtained from the 'Golden Giant' variety, i.e. $530.3 \mathrm{~kg} \mathrm{ha}^{-1}$, and less from the 'Bolivia 153' variety, respectively, $280.0 \mathrm{~kg} \mathrm{ha}^{-1}$ (Table 9). 
Table 9. Protein production of Amaranthus cruentus $\left(\mathrm{kg} \mathrm{ha}^{-1}\right)$ (Reviga experimental field)

\begin{tabular}{|c|c|c|c|c|}
\hline Variety & $\begin{array}{c}\text { Average of grains yields } \\
\left(\mathrm{kg} \mathrm{ha}^{-1}\right)\end{array}$ & $\begin{array}{l}\text { Production of proteins } \\
\qquad\left(\mathrm{kg} \mathrm{ha}^{-1}\right)\end{array}$ & Difference of average & Significance \\
\hline \multicolumn{5}{|c|}{2017} \\
\hline 'Bolivia 153' & 1822 & 280.0 & -42.3 & ooo \\
\hline 'Golden Giant' & 2181 & 366.8 & 44.5 & *** \\
\hline Average & 2002 & 322.3 & Control & - \\
\hline \multicolumn{5}{|c|}{ LSD $5 \%=2.25 \mathrm{~kg} \mathrm{ha}^{-1} ;$ LSD $1 \%=3.62 \mathrm{~kg} \mathrm{ha}^{-1} ;$ LSD $0.1 \%=5.25 \mathrm{~kg} \mathrm{ha}^{-1}$} \\
\hline \multicolumn{5}{|c|}{2018} \\
\hline 'Bolivia 153' & 2933 & 445.8 & -41.7 & ooo \\
\hline 'Golden Giant' & 3114 & 530.3 & 42.8 & $* * *$ \\
\hline Average & 3023 & 487.5 & Control & - \\
\hline
\end{tabular}

The high protein content of the 'Golden Giant' variety is noticeable, of over 16\% in 2017 and over 17\% in 2018. This proves the superiority of the grains of this variety which exceeded the average very significantly in both years of experimentation compared to the common wheat which has on average around $12-14 \%$.

\section{Conclusions}

On average, for two years of experiments, the two varieties of Amaranthus were sowing in the second decade of April (April 17-19), plants emerged after 12-15 days, during the first decade of May and flowering in the last decade of June. From a morphological point of view, amaranth plants were characterized by: 149.8$166.7 \mathrm{~cm}$ of height plants; $12-13$ steam nodes per plant; 36-38 leaves per plant and 3,301.6-3,357.7 cm-2 plant ${ }^{1}$ Leaf Area Index. The harvest maturity was reached in the first decade of September, after 124-127 days of vegetation, in which 839.3-842.4 GDD were accumulated. The productivity elements showed: 92,000-98,000 plants per ha - density of plants; 18.23-31.63 $\mathrm{g}_{\text {grains plants }}{ }^{-1}$; $1.37-1.59 \mathrm{~g}$ TWG. In terms of chemical composition, amaranth grains contain on average: $15.20-17.03 \%$ proteins; $51.45-53.2 \%$ starch; $6.41-7.11 \%$ lipids; $5.05-6.67 \%$ cellulose; $3.10-3.41 \%$ ash. In both years of research, the most productive variety proved to be the 'Golden Giant' variety, which yield was over 3,000 kg ha-1 and around $400 \mathrm{~kg} \mathrm{ha}^{-1}$ proteins. Regarding organic agriculture technology for growing, it is recommended to sow the Amaranthus cruentus varieties in the second half of April, at the distance $50 \mathrm{~cm}$ between rows and density of 100,000 grains ha ${ }^{-1}$. For weed control, repeated weeding will be applied whenever necessary, manual or mechanical. In conclusion, Amaranthus species reflect a good ability to adapt to the conditions of south part of Romania, and cultivation in organic agriculture conditions, with good yields and high level of quality grains.

\section{Authors' Contributions}

The authors contributed equally to the writing of the paper. All authors read and approved the final manuscript.

\section{Acknowledgements}

This research received no specific grant from any funding agency in the public, commercial, or not-forprofit sectors. 
Toader M et al. (2020). Not Bot Horti Agrobo 48(3):1413-1425

\section{Conflict of Interests}

The authors declare that there are no conflicts of interest related to this article.

\section{References}

Alvarez-Jubete L, Arendt EK, Gallagher E (2010). Nutritive value of pseudo-cereals and their increasing use as functional gluten-free ingredients. Trends in Food Science and Technology 21(2):106-113. https://doi.org/10.1016/j.tifs.2009.10.014

Akin-Idowu P (2017). Nutritional evaluation of five species of grain amaranth - an underutilized crop. International Journal of Sciences 18-27. https://doi.org/10.18483/ijSci.1131

Artemyeva EP, Valdayskikh VV, Radchenko TA, Belyaeva PA (2019). Amaranthus phenology during its introduction in the Middle Urals. American Institute of Physics (AIP) Conference Proceedings 2063, 030002 https://doi.org/10.1063/1.5087310

Cole C (1979). Amaranth from the past for the future. Rodale Press Inc, Emmaus Pennsylvania, USA.

Das S (2016). Amaranthus: a promising crop of future. Springer Science and Business Media Singapore. Retrieved 2020 March 20 from https://link.springer.com/book/10.1007\%2F978-981-10-1469-7

Duwayri AM (2001). Crop diversification in the Asia-Pacific region. In: Crop Diversification in the Asia-Pacific Region. FAO Regional Office for Asia and the Pacific. Retrieved 2020 June 12 from http://www.fao.org/3/x6906e/x6906eOg.htm

Erten E, Rossi C, Yuzugullu O, Hajnsek I (2014). Phenological growth stages of paddy rice according to the BBCH scale and SAR images. In: 2014 IEEE Geoscience and Remote Sensing Symposium, pp 1017-1020. https://doi.org/10.1109/IGARSS.2014.6946600

FAO (2017). The future of food and agriculture - Trends and challenges. FAO report, Rome. Retrieved 2020 March 12 from $h t t p: / / w w w . f a o . o r g / 3 / a-i 6583$ e.pdf

Gilmore EC, Rogers J (1958). Heat units as a method of measuring maturity in corn. Agronomy Journal 50:611-615. https://doi.org/10.2134/agronj1958.00021962005000100014x

Giuliani A, Hintermann F, Rojas W, Padulosi S (2012). Biodiversity of Andean grains: Balancing market potential and sustainable livelihoods. Biodiversity International and the Bern University of Applied Sciences, School of Agricultural, Forest and Food Sciences (HAFL). Retrieved 2020 June 10 from https://www.bioversityinternational.org/fileadmin/_migrated/uploads/tx_news/

Biodiversity_and_Andean_grains_balancing_market_potential_and_sustainable_livelihoods_1635.pdf

Innovation NRCACT (1984). Amaranth: modern prospects for an ancient crop. National Academy Press, Washington, DC. https://doi.org/10.17226/19381

Isleib J (2012). Exploring alternative field crops. These alternative crops involve both risks and opportunities. Michigan $\begin{array}{lllllll}\text { State University } & \text { Extension. } & \text { Retrieved } & 2020 & \text { June } & 12 & \text { from }\end{array}$ https://www.canr.msu.edu/news/exploring_alternative_field_crops

Haros CM, Schoenlechner R (2017). Pseudocereals: chemistry and technology. John Wiley \& Sons, UK.

Marin DI, Bolohan C, Mihalache M, Rusu T (2011). Research on Amaranthus cruentus L. and Amaranthus hypochondriachus L. species grown in South-Easter Romania (Moara Domnească - Ilfov). Scientific Papers Series A, Agronomy 54:297-303.

Martínez-Núñeza M, Ruiz-Rivas M, Vera-Hernándeza PF, Bernal-Muñoz R, Luna-Suáreza S, Rosas-Cárdenas FF (2019). The phenological growth stages of different amaranth species grown in restricted spaces based in BBCH code. South African Journal of Botany 124:436-443. https://doi.org/10.1016/j.sajb.2019.05.035

Nadathur $S$ (2016). Amaranth-sustainable crop for the 21 st century: food properties, and nutraceuticals for improving human health. Sustainable Protein Sources, $1^{\text {st }}$ Edition: Chapter 15, Elsevier. https://doi.org/10.1016/B978-012-802778-3.00015-9

Najdi Hejazi S, Orsat V, Azadi B, Kubow S (2016). Improvement of the in vitro protein digestibility of amaranth grain through optimization of the malting process. Journal of Cereal Science 68:59-65. https://doi.org/10.1016/j.jcs.2015.11.007 
Orona-Tamayo D, Paredes-Lopez O (2017). Amaranth part 1 - sustainable crop for the 21st century: food properties and nutraceuticals for improving human health. S Nadathur (Ed). Sustainable Protein Sources, ${ }^{\text {st }}$ Edition, Chapter: 15, Publisher: Elsevier. https://doi.org/10.1016/B978-0-12-802778-3.00015-9

Rani R (2017). Genetic divergence and evaluation of grain amaranth (Amaranthus hypochondriacus L.) germplasm. Master Thesis of Birsa Agricultural University Ranchi - 834006 (JHARKHAND). Retrieved 2020 June 10 from https://pdfs.semanticscholar.org/65a4/c08f7b7b8da64b91dbf1bf3f31e6d75f98fb.pdf

Rastogi A, Shukla $S$ (2013). Amaranth: a new millennium crop of nutraceutical values. Critical reviews in food science and nutrition 53(2):109-25. https://doi.org/10.1080/10408398.2010.517876

Robert LD (1996). Amaranth: new crop opportunity. In: Janick J (Ed). Progress in new crops. ASHS Press, Alexandria, VA. New York, USA.

Rusu T, Marin DI, Moraru PI, Ciontu C, Mihalache M, Moraru PI, Pop LI (2009). Researches on Amaranthus sp., seed and biomass production in pedoclimatic conditions of Somesan Plateau. Bulletin of University of Agricultural Sciences and Veterinary Medicine Cluj-Napoca. Agriculture 67(1):242-246.

Toader M, Roman GhV (2011). Chemical composition and yields quality of pseudo-cereals in Romanian agriculture conditions. In: Climate change: challenges and opportunities in agriculture. AGRISAFE Final Conference, 21 23 March 2011, Budapest, Hungary. Proceedings pp 466-468. Agricultural Research Institute of the Hungarian Academy of Sciences.

Tonnang H, Makumbi D, Craufurd P (2018). Methodological approach for predicting and mapping the phenological adaptation of tropical maize (Zea mays L) using multi-environment trials. Plant Methods 14:108 https://doi.org/10.1186/s13007-018-0375-7

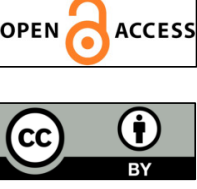

\footnotetext{
The journal offers free, immediate, and unrestricted access to peer-reviewed research and scholarly work. Users are allowed to read, download, copy, distribute, print, search, or link to the full texts of the articles, or use them for any other lawful purpose, without asking prior permission from the publisher or the author.

License - Articles published in Notulae Botanicae Horti Agrobotanici Cluj-Napoca are Open-Access, distributed under the terms and conditions of the Creative Commons Attribution (CC BY 4.0) License. (c) Articles by the authors; UASVM, Cluj-Napoca, Romania. The journal allows the author(s) to hold the copyright/to retain publishing rights without restriction.
} 